\title{
Muslim Women in India: A Media Perception
}

\author{
Dr. Badruddin
}

\begin{abstract}
Muslim women, media, mind and society- all are debated topics now and then in India. Ever since the creation of Indian constitution, Muslim women have been viewed as conservative due to social stigma. Purdah system, limited role of Islamic Organizations, codification of law, gender politics, marriage, dress code and religion have hindered the emancipation of women in social life. Indian and several western media continue to project Muslims Women for their limited participation in society. The paper also examines the status of Muslim women in Indian sub continent by re-establishing the essence from an authentic Islamic perspective. Extensive data are being used from various literary and online sources to compile the information about Muslim Women in India.
\end{abstract}

Index Terms - Muslim Women, India, Media, Mind, Legislation

\section{BACKGROUND}

Muslim women represent roughly $7 \%$ of India's population compared to $40 \%$ Hindu women. Most commonly large sections of Muslim women are viewed as poor, less educated, non- progressive, and superstitious. Very often, Muslim Women are considered a threat to national security projected by several media. It is therefore imperative to understand the hidden philosophy of Islam and status of Muslim women in broader democratic perspective in India.

Historically speaking, it was Mohammedan Anglo Mao Oriental College (1857) established by Sir Syed Ahmed Khan, the intellectual founder of Aligarh Muslim University which played greater role to uplift the status of Muslim women. Role of "Indian Muslim women" in the freedom movement has been well documented. Inspired by Mahatma Gandhi and Maulana Azad, number of women joined the struggle against British Raj. Muslim Women also encouraged their husbands, fathers and sons to take active part in India's freedom movement. They joined both non-violent as well as violent movements against the foreign rule. Some prominent ones: Begum Hazrat Mahal (wife of Nawab Wajid Ali Shah), Zubaida Daoodi (wife of Maulana Shafi Daoodi), Azizan (freedom fighter), Amjadi Begum (wife of Maulana Mohammad Ali Johar) and Sadat Bano Kichlew, (wife of Dr. Saifuddin Kichlew). Some around 225 names are recored durign freedom struggle but were not duly acknbowleged during post independent India. ${ }^{[1]}$.

Muslims of South Asia have been inspired by the notion of Pan-Islamism where some of them start identifying with a more scrutinized version of Islam. Constitutional framers of India adopted European Model of Secularism based on neutral and negative character outside the religious purview. ${ }^{[2]}$. During

Dr. Badruddin, Associate Professor (Political Science), PES's RSN College of Arts \& Science, Ponda, Goa, India post independence, large number of minority schemes were implemented. Ironically, Indian democracy virtually "collapsed into religious terror", but managed to survive due to the resilience of its political institutions and other supportive factors under the banner of Hindutva Lobby. Thereafter, both media as well policy makers played damaging role in patronizing the role of Indian Muslims by calling them as anti-nationalists. The stereotype image of Indian Muslims established by Indian popular media became the serious concern that increased virulent activities increased progressively: ${ }^{[3]}$. Ironically, however, India's secular democracy failed to evolve people to people oriented ideology where the greater need was felt to spread the true value of freedom. Unaccomplished attempt to incorporate spiritual tradition, unifying theology and secular traditions became the responsible agents and worked as social dividers. Indian Model of Development was found to be characterized by politicization of fragmented social structure. ${ }^{[4]}$. It gave the birth of separatist organisaitons as sizeable sections of them remained econmcially margianlsied and alienated as the role remained confined to purdah, kitchen, husband and children. NGOs like All India Muslim Women's Personal Law Board, IQRA International Women's Alliance, Nawaz-e- Niswan, Hamraz Legal Cell, Hukook-e-Niswan Sanghatana, Women's Research - Action Group, Muslim Women's Right Network, Bharatiya Muslim Mahila Andolan, Zakat Foundation and many more continue to work for the progress of Muslim women. Number of commissions also appeared with high and sounding ideologies that drew comprehensive documents though most of them remained unimplemented, resulting in the loss of interest of Indian Muslims and faith towards democratic governance. Recent controversy about Triple Talaq, Love Jihad, Ghar Wapsi (Back to Hinduism) and Suddhikaran (purification), miserably spread by India media and ruling rightist forces, have resulted into serious controversies.

As against the backdrop of in India's secular constitution, birth of powerful Muslim Organizations and NGOs were prompted to create secular credentials and to fight against Hindu appeasement. The prominent ones are : Centre for the Study of Society \& Secularism (Mumbai), Coalition of Voluntary Agencies (Hyderabad), Beti Foundation (Lucknow), Ahmadabad Community Foundation (Gujarat), Ghalib Academy (Delhi), etc are constructed to promote communal harmony. Gradually, however, it consolidated and strengthened the scope of All India Muslim Women Personal Law Board, and All India Mille Council and Service. Arguably, the inabilities of the administration to address against opportunistic approach failed to convince. ${ }^{[5]}$. Despite such 
initiatives at popular level, role of Muslim women continue to remain neglected in several scores.

\section{Muslim Women AND Role Of INTELLIGENTSIA}

More often Muslim Women in India are considered as narrow minded with limited participation. But is only one sided picture. Other side picture is more interesting and debated where media has been the focus of promoting the role of Muslim women. Top most beauty queens since fifties have been dominated film theatres and public domain that include glamorous heroines: Madhubala, Nargis, Wahida Rehman, Mumtaz, Surayya, Praveen Bobby, Meena Kumari and many more side actresses. Much more to speak, even during late nineties film celebrities like Tabbu, Sohal Ali, Jiah Khan, Farah Khan, Karina Kapoor Khan and Katrina Kaif are not less important for their glamour. If God has given them beauty and attraction, then why they should remain under veil. Even in politics, large number of Muslim women have been more successful. Some are Nazma Heptulla, Mohsina Kidwai, Mehmuda Mufti, Syeda Anwara Taimur, Shabana Azmi and Aruna Asaf Ali who have established identity in multidimensional political spheres. Few but exceptionally intellect women are also associated with teaching and research assignments in Aligarh Muslim University, Jamia Hamdard, Jamia Millia Islamia, Osmania University and Jawaharlal Nehru University. Miscellaneous services like media (Salma Sultan), Beautician (Shahnaz Hussein), NRI Yasmin Ratansi (Canadian Parliament), Uzma Naheed (Member: All India Muslim Personal Law Board), Shah Bano (Muslim Women Protection Act), Bilkis Bano (A Witness of Godhara still fighting for justice), Shazia Zalmi (BJP Leader), and many more are the inspiration for other Muslim women. But such examples are only on finger tips. Unfortunately, Muslim women largely failed to establish identity in several other streams like Medical Doctors, Engineers, Management Consultants, IAS-IPA-IFS Officers, Defense Services and miscellaneous high profile jobs and professions. But it is really a painful that less than one percent Muslim women belong to Intelligentsia group.

\section{Muslim Women In INDiA : SOME COMMON IDENTITIES}

Muslim Women of India constitute an important social segment and continue to remain in political whirlpool for variety of reasons. It is rather difficult to establish a common opinion. However, large number of studies through observation and social interaction can help to establish some common theories about Muslim women in India though it is not $100 \%$ fool proof. Several studies show that $80 \%$ Muslim women are not in favour of early marriage (below 18) which is more commonly found at urban segments including educated and enlightened community. A major sections of Muslim Women prefer marriage and establish family after 24 years of puberty only after successful entry in some profession. Whereas $40 \%$ hate to confine in Kitchen \& domestic works. Close to $75 \%$ women remain under the domination of their husbands. A report by Sachar Committee clearly shows that 35\% of Muslim women have never attended a school and probably women remain least qualified in India: ${ }^{[6]}$
The above data is commonly understood in broader public and media domain though diversities of opinion differ in terms of geography, social hierarchy and cultural variations. Panticipation of Muslim women in security related activities [Police, Army) is virtually nil and the presence of Muslims Women in top most cadre Indian and Management Consultants are not known. In a nutshell, the professional status Muslim women in India is far from satisfaction as reported by several media sources. Let all women-Hindus or Muslims be looked as par with Indians, freedom of press under democratic governance, hidden agenda of religious ethics need wider Publicity where governments should be proactive to create conducive environment. Implementation of Uniform Civil Code is the need of hour. Women should be given double protection: husband and father, and integration of a gender perspective in special budgetary programmes are important. There is a need to develop skill and capacity building-better to be stronger than beautiful where the change of parental attitude need dynamic decision. Women Platform for Action should be linked with rapid implementation.

\section{CONCLUSIONS}

Undoubtedly, Muslim women in India and their socio-economic profile, though less researched, provide interesting data and remain a debated topic now and then. Large section of them are neither opinion maker nor the decision maker. Most of them are largely marginalized, faceless and voiceless in their own social circle. Due to social stigma or otherwise, they are virtually kept silent to speak their wishes and views instead of opting open choice. Sizeable sections of Muslim women in India, unlike Islamic States including Gulf, do not have public access. Even during the age of globalization and economic liberalization, number of writers, leaders and consultants are virtually zero in India unlike several other Islamic and Muslim dominated countries like Turkey, Bangladesh, Malaysia and Indonesia where women have every freedom and equal footings with men. Studies also show that large number of Muslim women from Gulf, Middle East and South East Asia have established powerful entrepreneurship abilities in USA, UK, France, Germany and several other European countries. On the contrary, the picture is reverse or gloomy in India about the stand of Muslim women. Large number of their male counterparts are working in different capacity, mostly with labour segments in Gulf when their wives and children in India are not entitled for 'Family Visa' (Mostly in Arab States) due to non-skilled strata of jobs and stringent service conditions. However, such limitations are not restricted in Western counties. It is therefore advisable that Muslim women need to build cooperation between genders and communities to define their own needs, priorities and space by improving education and technical expertise in India.

Islam places the genders on equal footings without discrimination of sex, religion, place and community where all human beings are treated as equal. It is now right time to assess Muslim women's contributions, successes and failures as well as the formidable challenges that they face as members of the 
civil society. Purdah system - falsely liked with superstitions while the concept of Burqua represents laughing Image in India. Practically speaking, large number of non-Muslim women too adopt Hijaab (though in different style) to protect from environmental hazards like dust, heat, noise and other social pollutants. But the women of others communities are more confident while Muslim women in India are in miserable condition - largely marginalized, faceless and voiceless in their own social circle. Islam needs to be examined in broader perspectives while giving equal parity to all religions. It can done through free press under control of democratic governance, communal harmony, positive and motivational journalism. Implementation of Minority Programmes through greater resources, up gradation of skill, prosecution of communal offenses and recruitment in service sectors are valued imperatives for liberty, equality and justice.

\section{FINDINGS}

Psychology of woman is very complex and different from men. Muslim women should be allowed to speak their wishes and views instead only the "do's" and "don'ts with parity of uniform civil code and related commissions through Comprehensive Plan of Action. A cautious and careful implications of 'Fatwa of Mullas' must be kept in mind. It is high and right time to change the attitude of parents and elders. Education should not be confined to Madaris (Islamic Schools) only. There is a greater need to create a Platform for Action by promoting "policy of mainstreaming a gender vision at all levels" though Integration of a gender perspective in budgetary programmes. Even Muslim women in the repressed Arabian societies are clamouring for change (Iran, Egypt, Iraq, Bangladesh). Hence insignificant participation of Muslim women in Indian and in Muslim societies is a matter of concern. When Quran is clear in its philosophy, then whey why chadar (Hijab), choolha (Kitchen) and chardivari (social boundary) are so dominating for Muslim Women? It is a policy blunder, an undemocratic road to Hindu Rashtra, and decision of politicians to distract the minds of secular democracy. History can neither be changed nor re-written by the non secular forces. Let India come up with communal harmony, social security and planned economic policy rather than wasting time on unwanted petty experiments. Censorship on Indian media should be removed to respect the sentiments of secular democracy.

\section{REFERENCES}

[1] http://radianceweekly.in/portal/issue/muslims-and-1857-war-ofindepend ence/article/role-of- muslim-women-in-freedom-movement/

[2] Muchkund Dubey, "Challenges Facing Indian Secularism" in , D. D. Khanna \& others, ed., Democracy Diversity Stability: 50 years of Indian Independence, New Delhi : Mc Millan India Limited, 1998, pp.161-73.

[3] Sucheta Mahajan, "Hindu Communalism versus the Indian State 1947-1948" in V. Grover, ed., Indian Government \& Politics , New Delhi: Deep \& Deep Publications, 1998, pp.328- 29.

[4] Rajni Kothati, "Pluralist Politics in India: Cultural Roots, Recent Erosions" in, DD Khanna \& others, ed., Democracy Diversity Stability: 50 years of Indian Independence, New Delhi : Mc Millan India Limited, 1998, pp.75-103.

[5] Badrud-Din, "Election Manifestoes \& Minority Rights" Third Concept, Vol. 19, No.220, pp.19-23,p.19 June,2005 see also,
https://en.wikipedia.org/wiki/All_India_Muslim_Women\%27s_ Personal_Law_Board

[6] https://en.wikipedia.org/wiki/Sachar_Committee 